\title{
Potentiality of Secondary Aquifers in Saudi Arabia: Evaluation of Groundwater Quality in Jubaila Limestone
}

\author{
Mohammed Tahir Hussein ${ }^{1}$, Mazin M. Al Yousif ${ }^{2}$, Hussein S. Awad ${ }^{1}$ \\ ${ }^{1}$ SGSRC, Department of Geology, College of Science, King Saud University, Riyadh, Saudi Arabia \\ ${ }^{2}$ KACST, Riyadh, Saudi Arabia \\ Email: mhussein@ksu.edu.sa
}

Received September 11, 2011; revised October 16, 2011; accepted November 18, 2011

\begin{abstract}
Groundwater scarcity in arid regions may hinder development plans and cause many inconveniences for the population and authorities. Saudi Arabia has limited groundwater resources stored in the sedimentary sequence of the Arabian Shelf. Some of these resources were classified as major aquifers, secondary and minor aquifers, and some were considered as aquicludes. The Jubaila Limestone is one of the secondary aquifers of Saudi Arabia. The main purpose of this paper is to evaluate the groundwater resources of the Jubaila Limestone in Riyadh area, with emphasis on groundwater quality. Groundwater was found to occur in fractures and within solution openings of the Jubaila Limestone at depths which range between 19 and $210 \mathrm{~m}$. The transmissivity value was $1.7 \times 10^{-3}$ to $7.2 \times 10^{-3} \mathrm{~m}^{2} / \mathrm{s}$; the storage coefficient was of $1.3 \times 10^{-4}$. The electrical conductivity for collected water samples ranged between 831 and $7670 \mu \mathrm{S} / \mathrm{cm}$. The major ionic relationships were $\mathrm{Na}>\mathrm{Ca}>\mathrm{Mg}$ and $\mathrm{SO}_{4}>\mathrm{Cl}>\mathrm{HCO}_{3}$. The groundwater evolves from $\mathrm{NaCl}$ dominated at the southern end of the study area, into $\mathrm{Ca}, \mathrm{MgSO}_{4}$ water in the north. The main chemical process responsible of this variation was found to be dissolution of anhydrite and gypsum. The groundwater was not found suitable for drinking purposes but can be used by livestock and for some agricultural purposes.
\end{abstract}

Keywords: Saudi Arabia; Riyadh; Jubaila Limestone; Groundwater Quality; Dissolution

\section{Introduction}

Saudi Arabia, is by far the largest country in the Arabian Peninsula. It occupies a surface area of about 2.15 million $\mathrm{km}^{2}$. It is bordered in the north by Jordan, Iraq and Kuwait, in the east by the Persian Gulf with a coastline of $480 \mathrm{~km}$, in the south-east and south by Qatar, the United Arab Emirates, Oman and Yemen, and in the west by the Red Sea with a coastline of some $1750 \mathrm{~km}$. The country can be divided into 4 main physiographic units (Figure 1): the Western Mountains, the Central Hills, the Desert Regions, and the Coastal Regions.

Saudi Arabia has a desert climate characterized by extreme heat during the day, an abrupt drop in temperature at night, and slight, erratic rainfall. Because of the influence of a subtropical high-pressure system and the many fluctuations in elevation, there is considerable variation in temperature and humidity. A uniform climate prevails in Riyadh area. The average summer temperature is 45 degrees Centigrade, but readings of up to 54 degrees are common. The heat becomes intense shortly after sunrise and lasts until sunset, followed by comparatively cool nights. In the winter, the temperature seldom drops below 0 degree Centigrade but the almost total absence of humidity and the high wind-chill factor make a bitterly

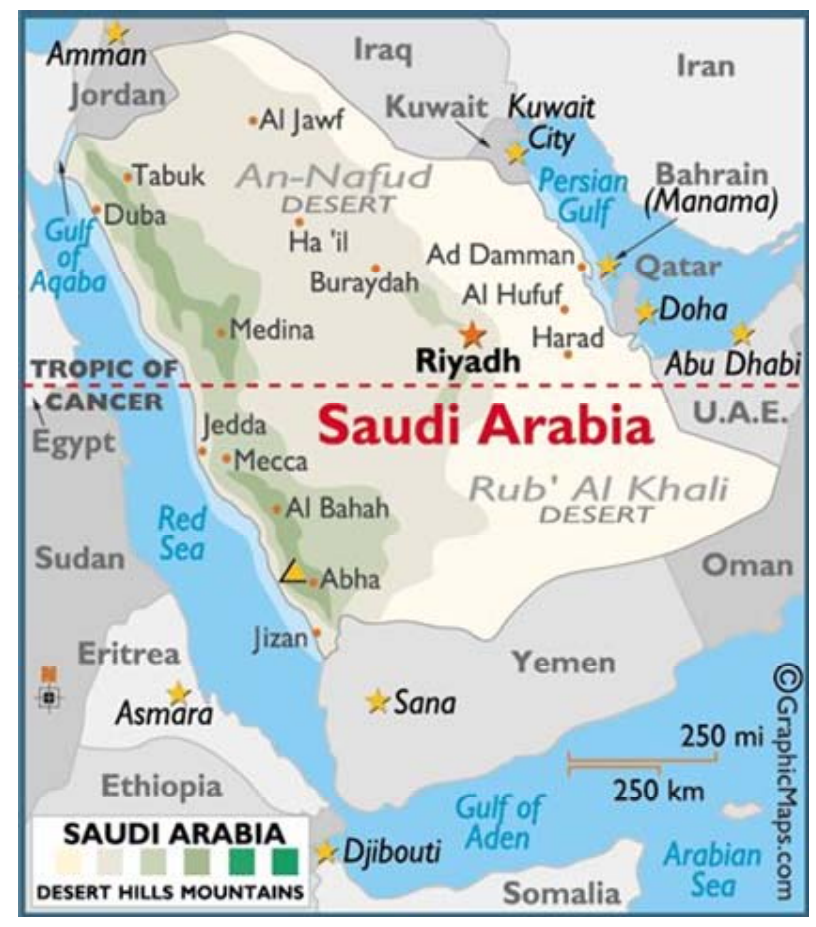

Figure 1. Map of Saudi Arabia illustrating the main physiographic features and the location of Riyadh. 
cold atmosphere. In the spring and autumn, temperatures average 29 degree Centigrade. The entire year's rainfall may consist of one or two torrential outbursts that flood the wadies and then rapidly disappear into the soil to be trapped above the layers of impervious rock. This is sufficient, however, to sustain forage growth. Although the average rainfall is 100 - 150 millimeters per year, the area may not experience rainfall for several years.

Geologically, the Kingdom of Saudi Arabia is divided into the Arabian Shield and the Arabian Shelf. The Shield is composed mainly of crystalline and crystallophyllian rocks primarily of Precambrian-Cambrian ages with volcanic lava flows of Tertiary-Quaternary age extending to recent years. Groundwater in the Arabian Shield occurs within the wadi deposits and in restricted area within the basaltic lava flows. The Arabian Shelf is mainly occupied by a sedimentary sequence lying uncomfortably on the basement rocks of the Shield and dipping towards the east and northeast. The sedimentary sequence starts with deposits of Cambrian ages and ends with Quaternary-recent deposits [1]. The sequence had been interrupted by a number of uncomformities during Phanerozoic. Table 1 summarizes the sedimentary sequence of the Jurassic Formations on the Arabian Shelf [2]. Within the Arabian Shelf groundwater is obtained from a number of aquifers ranging through Cambrian up to the Pliocene formations. The principal aquifers are the Saq, Wajiid, Qassim, Minjur, Dhurma, Wasia and Bayad, Umm er Radhuma, Dammam and Neogene aquifers. The Jubaila Limestone, according to the Water Atlas of Saudi Arabia [3] is classified as one of the secondary aquifers in Riyadh area. A. Al-Bassam, [4] considered the Jubaila Limestone as a moderate aquifer both as regards its quantitative and qualitative properties.

The water scarcity and the limited resources of water within the country make it necessary to look into the potentialities of the secondary aquifers and try to characterize its properties as possible. The main purpose of this study is to evaluate the groundwater quality in Jubaila Limestone, north of Riyadh between latitudes $24^{\circ} 45^{\prime}$ $24^{\circ} 55^{\prime} \mathrm{N}$ and longitudes $46^{\circ} 20^{\prime}-46^{\circ} 30^{\prime} \mathrm{E}$. The evaluation includes groundwater occurrences, movement, groundwater quality variation, chemical processes responsible for these quality variations and the suitability of water for various purposes.

\section{Methodology}

Based on the above-mentioned concerns, the methods used in this study included both field and laboratorial methods. Field methods included both geological and hydrogeological methods. The geological methods focused on identifying rock types, measurement and observation of geological features in the study area. The hydrogeological methods were concerned with preparing a well inventory sheet for all wells drilled in the study area. The collected information included well location using a GPS, measurements of static and pumping water levels using water-level sounders, discharge rate measurements using both containers and stopwatches, and collection of groundwater samples for analyzing their major, minor and trace elements. The laboratorial methods included the analyses of the collected groundwater samples and the data processing using AquaChem and PHREEQ softwares [5]. The analyses were performed according to APH/AWWA/WPCF [6]. Thirty wells were inventoried, sampled and analyzed for this study.

\section{Geology of the Study Area}

The study area is mainly occupied by the Shaqra Group sedimentary rocks. The Shaqra Group lies unconformably upon the Minjur Formation, of Late Triassic age, and is overlain by the Sulaiy Formation, of Berriasian age (Table 1). It is comprised of, in ascending stratigraphic order, the Marrat, Dhruma, Tuwaiq Mountain, Hanifa, Jubaila, Arab and Hith formations. These formations are separated by hiatuses of which the duration progressively decreases, as displayed on Table $\mathbf{1}$, where they are calibrated with the latest [7-9]. The Jurassic formations consist predominantly of carbonates, although evaporitic sediments become more prevalent in the Kimmeridgian and Tithonian Arab and Hith formations. Unlike the underlying red sandstone-dominated Minjur Formation, siliciclastics are uncommon in the carbonate-dominated Shaqra Group and mostly confined to the northern and southern margins of the outcrop belt where near-shore palaeoenvironments are inferred.

The Lower Jurassic succession includes the Marrat Formation, $102.5 \mathrm{~m}$ thick, that lies unconformably on the Triassic Minjur Formation, and consists of interbedded marine sandstone, carbonate and claystone deposits that are Toarcian or older in age. It is informally subdivided into lower (36.5 m), middle (41.8 m) and upper Marrat (24.2 m).

The Middle Jurassic is represented by the Dhruma and Tuwaiq Mountain formations. The Dhruma Formation, as defined here, is $336 \mathrm{~m}$ thick and lies unconformably on the Marrat Formation. It is mainly composed of carbonate in the subsurface, carbonate and claystone in the central part of the outcrop area, and siliciclastics in outcrops to the north and south. Tuwaiq Mountain Formation lies unconformably on the Dhruma Formation and consists mostly of shallow-marine lagoon and stromatoporoid carbonates of Middle to Late Callovian age with a combined thickness of $295 \mathrm{~m}$.

The Upper Jurassic succession consists of the Hanifa, Jubaila, Arab and Hith formations.

The Hanifa Formation lies disconformably upon the Tuwaiq Mountain Formation, is $126 \mathrm{~m}$ thick and consists 
Table 1. Jurassic stratigraphic column of Saudi Arabia (after Al Husseini, 2009).

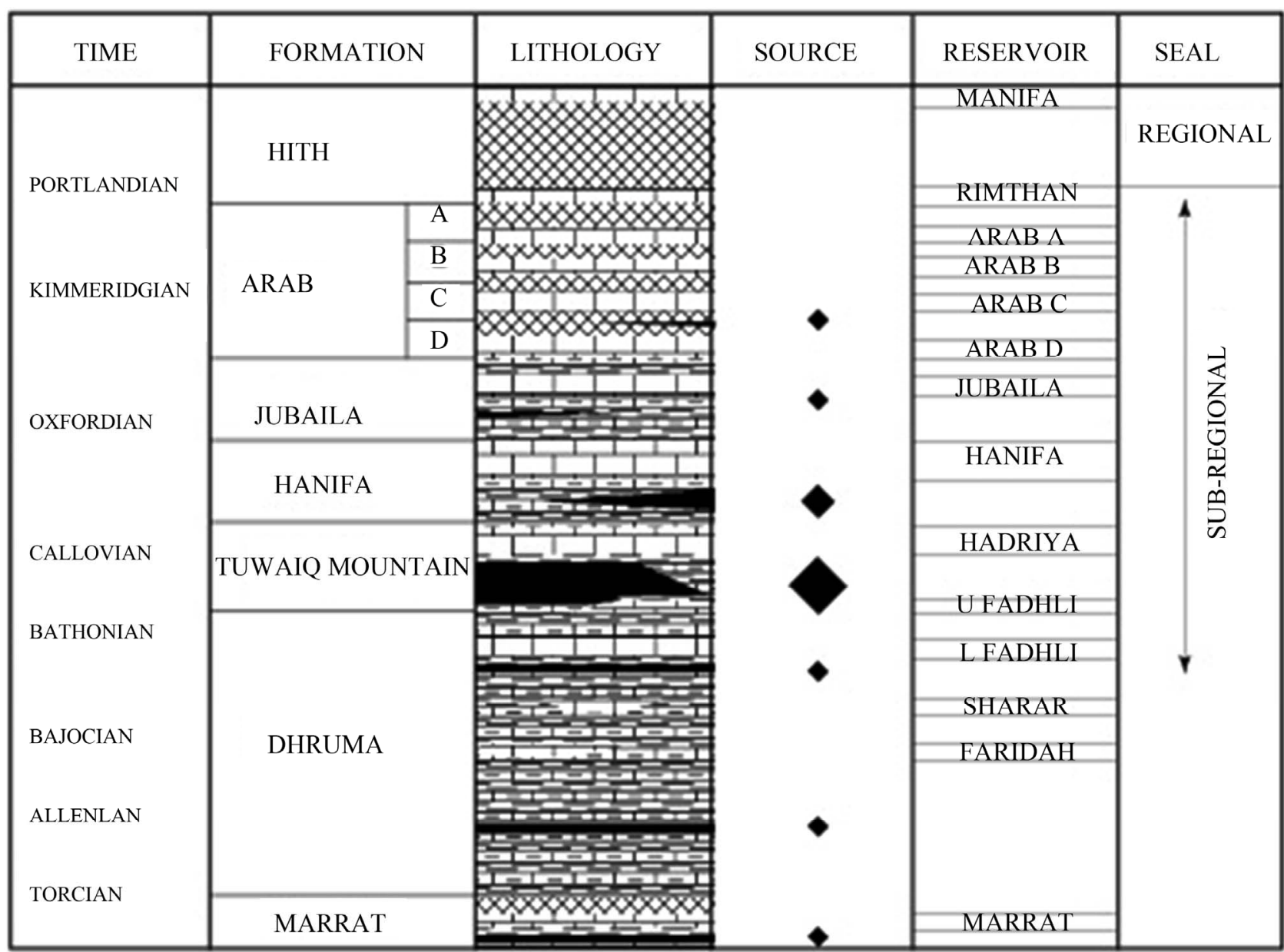

Evaporites

Organic-poor Mud/Packstone

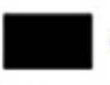

Organic-rich Mud/Packstone

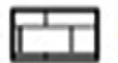

Limestone,Porous Grainstone

Jurassic Stratigraphic Column of Saudi Arabia

(after Carrigan et. al., 1995)

of a lower muddy carbonate unit and an upper stromatoporoid and lagoonal carbonate lithofacies. The Jubaila Limestone lies disconformably upon the Hanifa Formation and consists of moderately deep marine carbonates in the lower part that is overlain by a shallow marine stromatoporoid-associated assemblage. In the outcrop belt, the carbonates pass into sandstones to the south and northwest. The Arab Formation is approximately $54 \mathrm{~m}$ thick in outcrop. The Hith Anhydrite, consists mostly of anhydrite but has an upper carbonate unit, as described by Hughes [9]. It is $90 \mathrm{~m}$ thick at the outcrop [1].

\section{Groundwater in the Study Area}

Groundwater occurs in the Hubaila Limestone in zones characterized with secondary porosity created due to faulting, jointing, solution cavities and fractures. In areas well yields is found to be of high quantities and especially when these solution cavities are connected to wadies in the area [3]. The aquifer properties were estimated [1,10-12]. The Transmissivity was estimated during this study to be in the range between $1.7 \times 10^{-3}$ and $7.2 \times 10^{-3} \mathrm{~m} / \mathrm{s}$, and the Storage Coefficient was in the order of $1.3 \times 10^{-4}$.

Depth to water in the study area varied from some $19 \mathrm{~m}$ in wells nos., 21 and 22 to $210 \mathrm{~m}$ in well no. 10. Accordingly the elevation of the water table varied from $705 \mathrm{~m}$ above mean sea level, at well no. 30, in the northwest part of the study area to about $437 \mathrm{~m}$ at well no. 10 . Figure 2 shows the water table distribution in the study area and the direction of groundwater flow. In the northern part of the study area the groundwater flow followed 


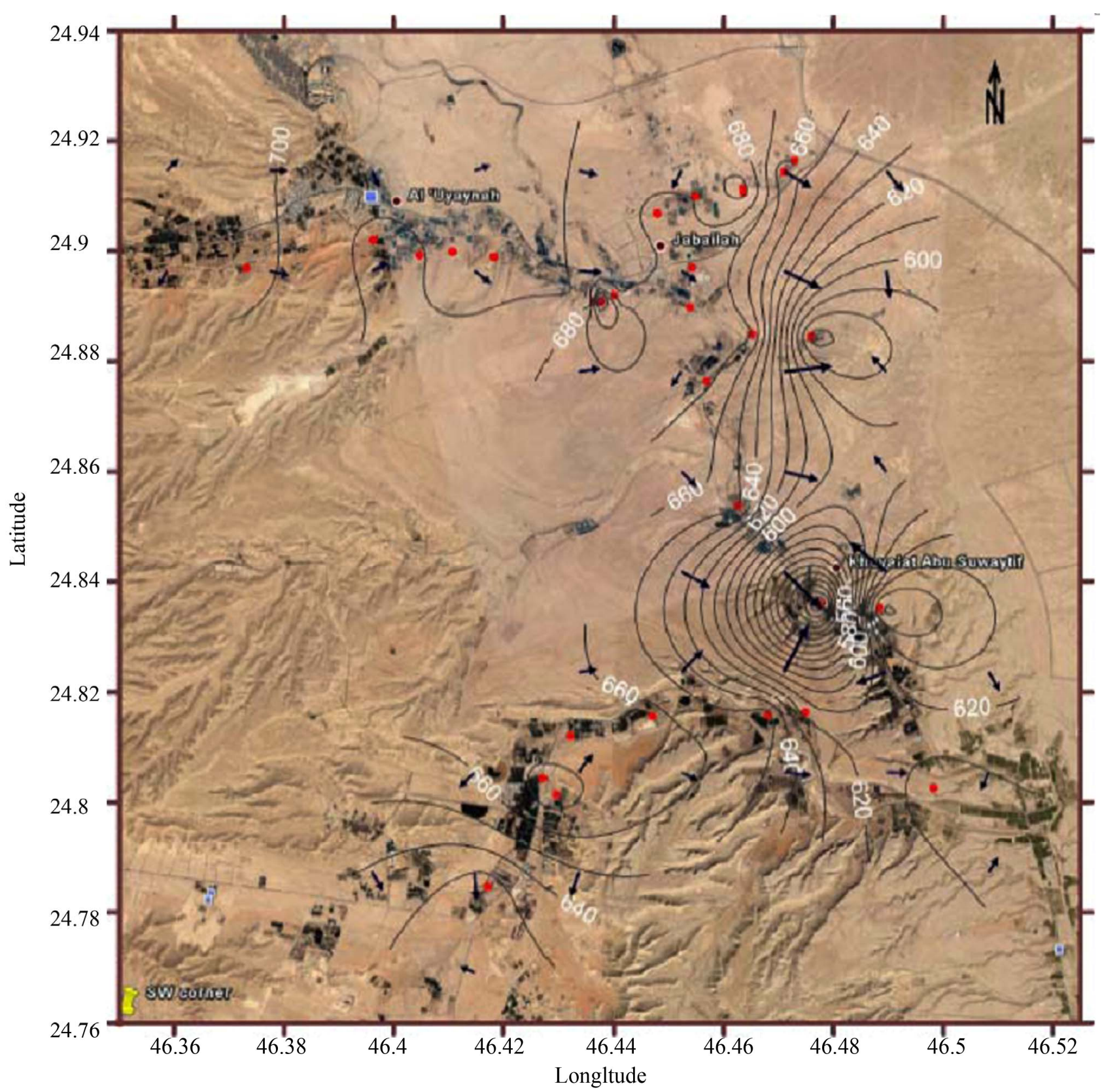

Water Table Elevation Map (arrows show approximate flow directions)

Figure 2. The red points are the locations of the inventored wells.

that of Wadi Hanifa as shown by the flow lines. At about the center of the study area a cone of depression was noticed around well no. 10. At the southern end of the area the direction of groundwater flow was towards the southeast and the south direction. The average hydraulic gradient is about 0.005 .

\subsection{Groundwater Quality Variation}

Groundwater quality in the study area varies greatly in its Electrical Conductivity (EC) from 831 to $7670 \mathrm{mS} / \mathrm{cm}$. This variation is due to interaction between hydraulic gradient, the nature of the water-bearing rocks and the chemical processes in action. Figure $\mathbf{3}$ shows the areal distribution of the EC in the study area. The general increase in EC is from the south towards the north of the study area where two major anomalies were noticed around the contour $6000 \mathrm{mS} / \mathrm{cm}$ and the contour 5000 $\mathrm{mS} / \mathrm{cm}$. This corresponds to the general direction of groundwater flow.

The main chemical composition of groundwater in the study area is summarized on Table 2 . The $\mathrm{pH}$ measured in the field is between 6.01 and 8.30 , i.e. it ranges from acidic 


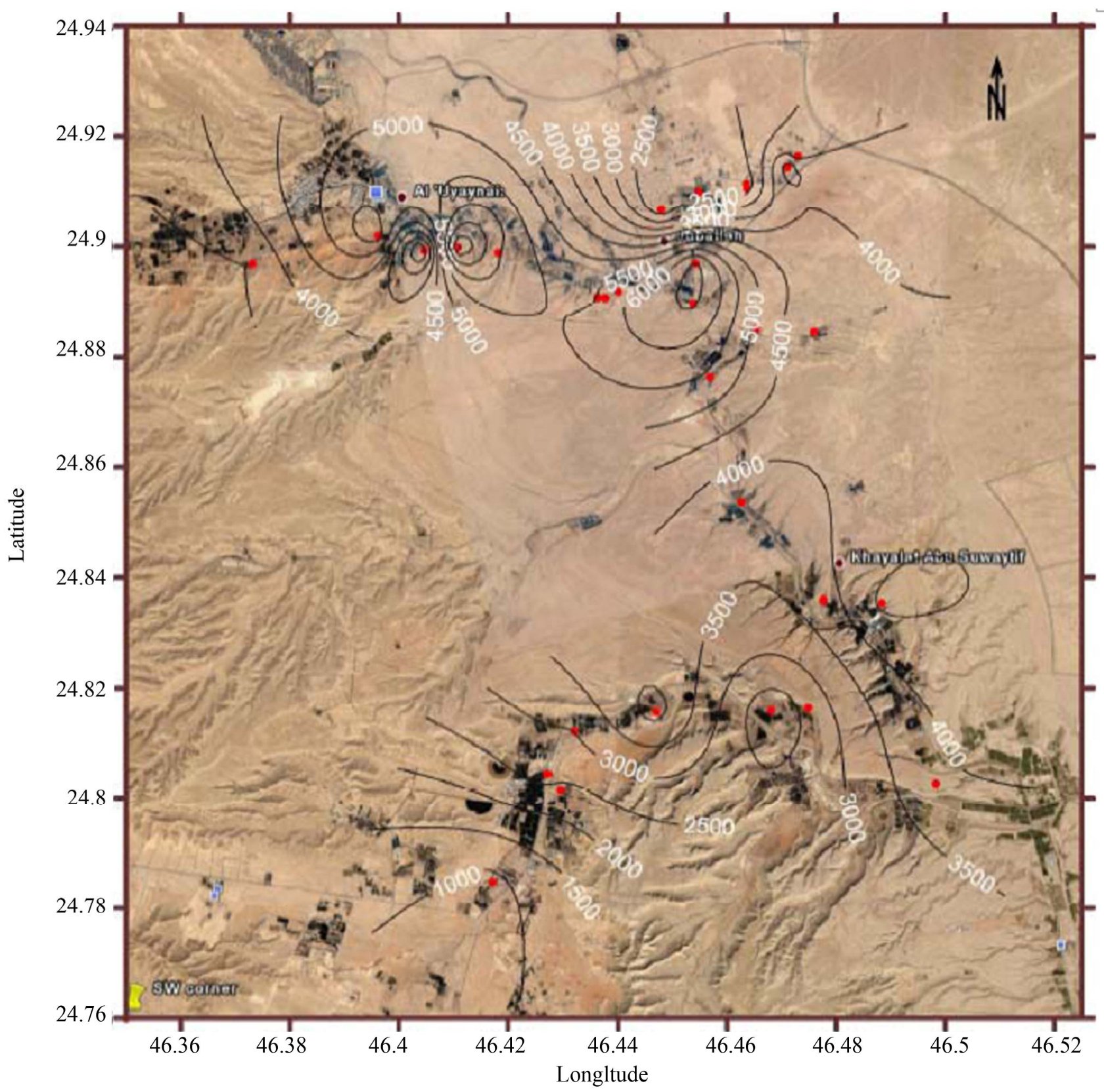

Figure 3. Spatial distribution of electerical conductivity (uS/cm).

water to alkaline. The same wide range in the composition was found in all of the major ions, the minor ions and the total hardness of groundwater as shown (Table 2). Table 3 shows the correlation Matrix of the analyzed chemical constituents. The EC was found to be mainly correlated with Hardness, $\mathrm{SO}_{4}^{2-}, \mathrm{Ca}, \mathrm{Mg}$ and $\mathrm{Cl}$. These ions seem to be the most responsible of the chemical composition and variation in the water quality in Jubaila Limestone. This is understood as the occurrence of groundwater in this aquifer is mainly due to solution openings and fractures within the formation. Harness is strongly correlated with the $\mathrm{Ca}, \mathrm{SO}_{4}^{2-}$. The $\mathrm{Ca}$ is, in turn correlated with the $\mathrm{Cl}$ and $\mathrm{SO}_{4}^{2-}$ concentrations, $\mathrm{Mg}$ is strongly correlated with $\mathrm{SO}_{4}^{2-}$, and, $\mathrm{Na}$ is strongly related to $\mathrm{Cl}$.

The ionic relationship, using the units of milliequivalent per litre (meq/L), in the Jubaila Limestone is characterized with the following:

$$
\begin{gathered}
\mathrm{Na}^{+}>\mathrm{Ca}^{2+}>\mathrm{Mg}^{2+} \\
\mathrm{SO}_{4}^{2-}>\mathrm{Cl}>\mathrm{HCO}_{3}^{-}
\end{gathered}
$$

To understand more the chemical variations in the groundwater system within the study area, a hydrochemical section was constructed. The location of this section is along the flow path from the south towards the 
Table 2. Summary statistics of groundwater composition in the study area.

\begin{tabular}{|c|c|c|c|c|c|c|c|}
\hline Variable & Mean & Minimum & Maximum & Range & Std. Dev. & Skewness & Kurtosis \\
\hline Temperature $\left({ }^{\circ} \mathrm{C}\right)$ & 25.033 & 17.6 & 30 & 12.4 & 2.487 & -0.815 & 2.466 \\
\hline $\mathrm{pH}$ & 7.215 & 6.01 & 8.38 & 2.37 & 0.435 & 0.49 & 2.99 \\
\hline $\mathrm{EC}(\mathrm{mS} / \mathrm{cm})$ & 4001.37 & 831 & 7670 & 6839 & 1717.26 & 0.287 & -0.782 \\
\hline Hardness (mg/L) & 1477.17 & 610 & 2740 & 2130 & 594.39 & 0.291 & -1.001 \\
\hline $\mathrm{Ca}(\mathrm{mg} / \mathrm{L})$ & 308.733 & 92 & 608 & 516 & 148.012 & 0.172 & -0.995 \\
\hline $\mathrm{Mg}(\mathrm{mg} / \mathrm{L})$ & 172.823 & 46.3 & 298 & 251.7 & 68.308 & 0.048 & -1.084 \\
\hline $\mathrm{Na}(\mathrm{mg} / \mathrm{L})$ & 680.243 & 365.45 & 1075.22 & 710.77 & 225.336 & 0.137 & -1.37 \\
\hline $\mathrm{K}(\mathrm{mg} / \mathrm{L})$ & 8.967 & 3 & 24 & 21 & 5.288 & 1.661 & 2.162 \\
\hline $\mathrm{HCO}_{3}(\mathrm{mg} / \mathrm{L})$ & 180.433 & 90 & 392 & 302 & 66.884 & 1.732 & 3.279 \\
\hline $\mathrm{SO}_{4}(\mathrm{mg} / \mathrm{L})$ & 1057.47 & 197 & 1822 & 1625 & 341.95 & 0.065 & 0.434 \\
\hline $\mathrm{NO}_{3}(\mathrm{mg} / \mathrm{L})$ & 18.233 & 1.25 & 37.5 & 36.25 & 10.157 & 0.211 & -0.59 \\
\hline $\mathrm{SiO}_{2}(\mathrm{mg} / \mathrm{L})$ & 12.708 & 5 & 42.5 & 37.5 & 7.536 & 2.362 & 7.666 \\
\hline $\mathrm{Fe}(\mathrm{mg} / \mathrm{L})$ & 0.168 & 0.001 & 0.088 & 0.879 & 0.188 & 1.963 & 5.991 \\
\hline B (mg/L) & 0.565 & 0.1117 & 0.9846 & 0.8729 & 0.279 & -0.139 & -1.142 \\
\hline Mn (mg/L) & 0.004 & 0.00239 & 0.01581 & 0.01342 & 0.003 & 2.936 & 8.422 \\
\hline
\end{tabular}

Table 3. Correlation matrix.

\begin{tabular}{|c|c|c|c|c|c|c|c|c|c|c|c|c|c|c|}
\hline Variable & $\begin{array}{c}\mathrm{EC} \\
(\mathrm{mS} / \mathrm{cm})\end{array}$ & $\begin{array}{l}\text { Hardness } \\
(\mathrm{mg} / \mathrm{L})\end{array}$ & $\begin{array}{c}\mathrm{Ca} \\
(\mathrm{mg} / \mathrm{L})\end{array}$ & $\begin{array}{c}\mathrm{Mg} \\
(\mathrm{mg} / \mathrm{L})\end{array}$ & $\begin{array}{c}\mathrm{Na} \\
(\mathrm{mg} / \mathrm{L})\end{array}$ & $\begin{array}{c}\mathrm{K} \\
(\mathrm{mg} / \mathrm{L})\end{array}$ & $\begin{array}{c}\mathrm{HCO}_{3} \\
(\mathrm{mg} / \mathrm{L})\end{array}$ & $\begin{array}{c}\mathrm{SO}_{4} \\
(\mathrm{mg} / \mathrm{L})\end{array}$ & $\begin{array}{c}\mathrm{Cl} \\
(\mathrm{mg} / \mathrm{L})\end{array}$ & $\begin{array}{c}\mathrm{NO}_{3} \\
(\mathrm{mg} / \mathrm{L})\end{array}$ & $\begin{array}{c}\mathrm{SiO}_{2} \\
(\mathrm{mg} / \mathrm{L})\end{array}$ & $\begin{array}{c}\mathrm{Fe} \\
(\mathrm{mg} / \mathrm{L})\end{array}$ & B (mg/L) & $\begin{array}{c}\mathrm{Mn} \\
(\mathrm{mg} / \mathrm{L})\end{array}$ \\
\hline $\mathrm{EC}(\mathrm{mS} / \mathrm{cm})$ & 1 & 0.975 & 0.908 & 0.867 & 0.73 & 0.017 & 0.137 & 0.932 & 0.875 & 0.532 & 0.153 & 0.182 & 0.166 & 0.123 \\
\hline Ca (mg/L) & & & 1 & 0.669 & 0.653 & -0.226 & -0.053 & 0.811 & 0.861 & 0.554 & 0.13 & 0.304 & 0.288 & 0.028 \\
\hline Mg (mg/L) & & & & 1 & 0.521 & 0.158 & 0.211 & 0.841 & 0.693 & 0.445 & 0.063 & 0.052 & 0.144 & 0.246 \\
\hline $\mathrm{Na}(\mathrm{mg} / \mathrm{L})$ & & & & & 1 & 0.128 & 0.011 & 0.746 & 0.902 & 0.295 & 0.545 & 0.075 & 0.042 & 0.19 \\
\hline $\mathrm{K}(\mathrm{mg} / \mathrm{L})$ & & & & & & 1 & 0.393 & 0.099 & -0.04 & -0.016 & 0.26 & -0.239 & 0.047 & 0.215 \\
\hline $\mathrm{HCO}_{3}(\mathrm{mg} / \mathrm{L})$ & & & & & & & 1 & 0.183 & -0.11 & -0.248 & -0.047 & 0.177 & 0.236 & 0.073 \\
\hline $\mathrm{SO}_{4}(\mathrm{mg} / \mathrm{L})$ & & & & & & & & 1 & 0.785 & 0.464 & 0.268 & 0.054 & 0.16 & 0.096 \\
\hline $\mathrm{Cl}$ (mg/L) & & & & & & & & & 1 & 0.461 & 0.358 & 0.196 & 0.122 & 0.194 \\
\hline $\mathrm{NO}_{3}(\mathrm{mg} / \mathrm{L})$ & & & & & & & & & & 1 & 0.018 & -0.156 & 0.279 & 0.115 \\
\hline $\mathrm{SiO}_{2}(\mathrm{mg} / \mathrm{L})$ & & & & & & & & & & & 1 & 0.127 & -0.061 & -0.14 \\
\hline $\mathrm{Fe}(\mathrm{mg} / \mathrm{L})$ & & & & & & & & & & & & 1 & 0.121 & -0.08 \\
\hline B (mg/L) & & & & & & & & & & & & & 1 & 0.31 \\
\hline $\mathrm{Mn}(\mathrm{mg} / \mathrm{L})$ & & & & & & & & & & & & & & 1 \\
\hline
\end{tabular}

north. $\mathrm{Ca}^{2+}, \mathrm{Mg}^{2+}, \mathrm{Na}^{+}$(Figure 4(a)) illustrate a gradual increase in their concentrations with the flow line, the same is shown for the $\mathrm{SO}_{4}^{2-}$ and the $\mathrm{Cl}^{-}$evolution (Figure 4(b)). The $\mathrm{HCO}_{3}$ exhibits a different trend, not related with the flow direction. It can be related to very limited rainfall in the study area. These findings reflect the effect of dissolution of gypsum and anhydrite minerals within the Jubaila Limestone.

\subsection{Hydrochemical Facies}

Hydrochemical facies are bodies of water with separate but distinct chemical compositions contained in an aquifer. Each hydrochemical facies defines a group of groundwater with similar composition. Each facies typically has a unique origin and or pattern of evolution [13]. Hydrochemical Facies provides some insight into the environmental processes that have affected a site and that 


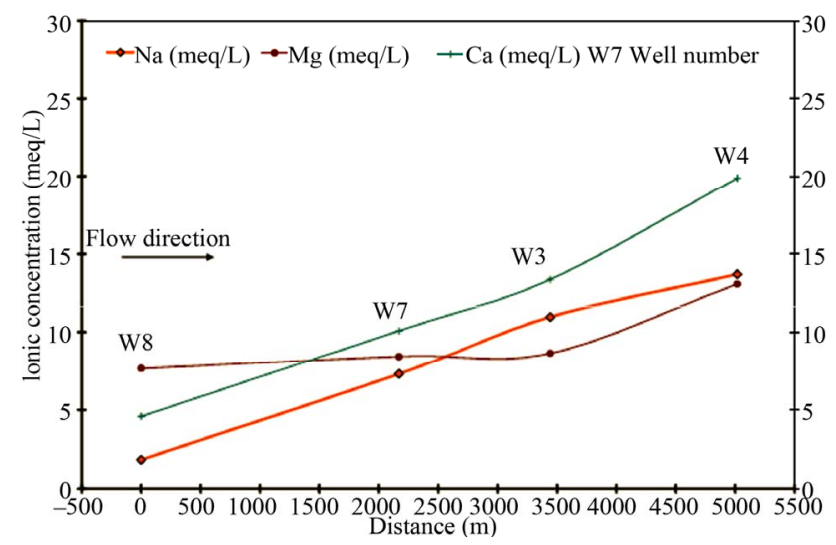

(a)

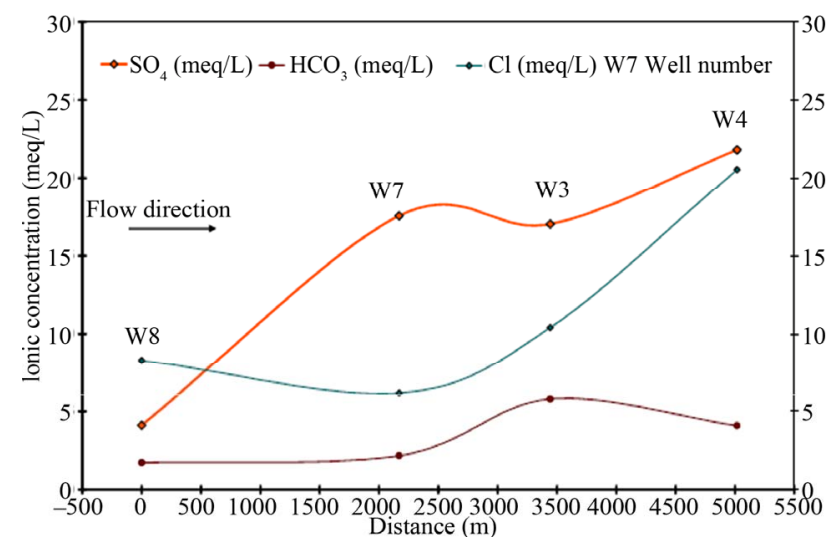

(b)

Figure 4. Hydrochemical crossection showing major ion evolution along flow line.

might continue its effect in future. For defining the hydrochemical facies present in the Jubaila Limestone aquifer, Piper Diagram has been constructed for the collected samples $[14,15]$. The plots of the collected and analyzed groundwater samples is shown on Figure 5. 50\% of the collected samples belong to the hydrochemical facies:

$\mathrm{Na}^{+}-\mathrm{Ca}^{2+}-\mathrm{Mg}^{2+}-\mathrm{Cl}^{-}-\mathrm{SO}_{4}^{2-} .27 \%$ of the samples belong to the hydrochemical facies: $\mathrm{Na}^{+}-\mathrm{Mg}^{2+}-\mathrm{Cl}^{-}-\mathrm{SO}_{4}^{2-}$ and $17 \%$ are $\mathrm{Na}^{+}-\mathrm{Mg}^{2+}-\mathrm{Ca}^{2+}-\mathrm{Cl}^{-}-\mathrm{SO}_{4}^{2-}$. The hydrochemical facies $\mathrm{Na}^{+}-\mathrm{Ca}^{2+}-\mathrm{Cl}^{-}-\mathrm{SO}_{4}^{2-}$ represent only $7 \%$ of the analyzed samples. The spatial distribution of these facies is illustrated on Figure 6. The groundwater evolves from $\mathrm{NaCl}$ dominated at the southern end of the study area, into $\mathrm{Ca}, \mathrm{Mg} \mathrm{\textrm {SO } _ { 4 }}$ water in the north i.e. in the downstream direction of the flow line. The main process responsible for this evolution is mainly dissolution of mineral as stated above. The dissolution of the minerals calcite and dolomite, dominant in the Jubaila Limestone can take place as:

$$
2 \mathrm{CaCO}_{3}+\mathrm{H}_{2} \mathrm{CO}_{3} \quad \mathrm{Ca}_{2}+2 \mathrm{HCO}_{3}
$$

2Ca, $\mathrm{Mg}\left(\mathrm{CO}_{3}\right)_{2}+2 \mathrm{H}_{2} \mathrm{CO}_{3} \quad \mathrm{Ca}_{2}+\mathrm{Mg}_{2}+4 \mathrm{HCO}_{3}$

The dissolution of halite and gypsum are as follows:

$$
\begin{aligned}
\mathrm{NaCl} & \mathrm{Na}^{+}+\mathrm{Cl}^{-} \\
2 \mathrm{CaSO}_{4} \cdot 2 \mathrm{H}_{2} \mathrm{O} & \mathrm{Ca}_{2}+\mathrm{SO}_{4}+2 \mathrm{H}_{2} \mathrm{O}
\end{aligned}
$$

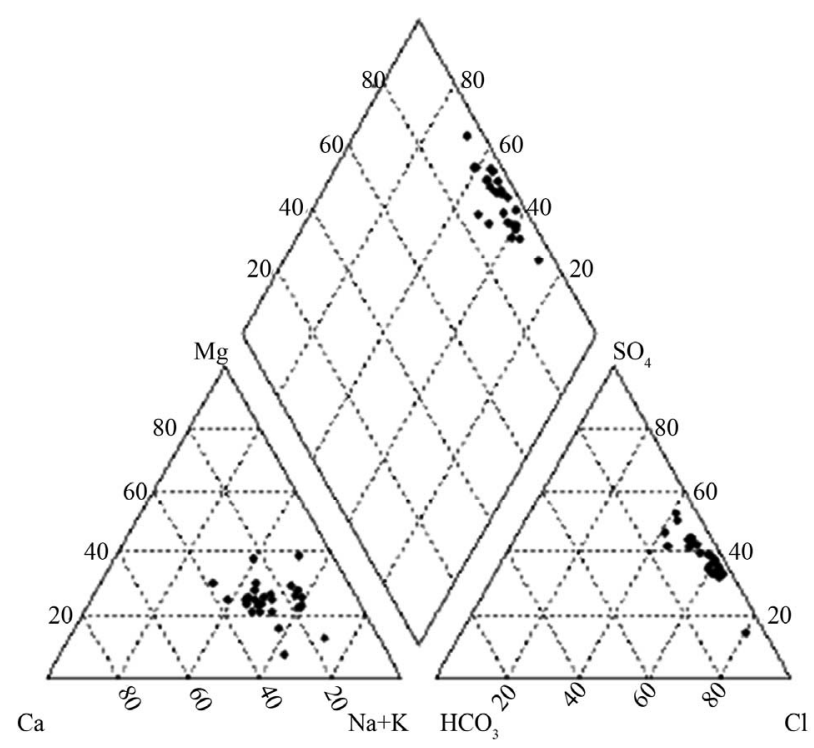

Figure 5. Trilinear diagram.

\subsection{Saturation Index}

The saturation index (SI) is the logarithm of the quotient of the ion-activity product (IAP) and the solubility product (K). The IAP is the product of element activity. Analytically determined concentrations have to be transformed to activities considering ionic strength, temperature and complex formation. The solubility-product is the maximum possible solubility at the respective water temperature.

\section{$\mathrm{SI}=\log \mathrm{IAP} / \mathrm{K}$}

SI indicates if a solution is in equilibrium, undersaturated or super-saturated with regard to a solid phase. A value of 1 signifies a tenfold super-saturation, a value of -2 a hundred fold under-saturation in relation to a certain mineral phase. Equilibrium can be assumed for a range of -0.5 to 0.5 . If the SI value is below -0.5 , the solution is under-saturated with regard to the corresponding mineral, if the SI exceeds +0.5 the water is super-saturated with respect to this mineral.

Table 4 shows the saturation indices for the minerals calcite, dolomite, gypsum and anhydrite in the collected water samples. Most of the samples were found in equilibrium or super- saturated with calcite and dolomite. The SI for calcite ranges between 0.93 to 0.99 (Figure 7), and that for dolomite is between 1.8 and 2.93 (Figure 8). $77 \%$ of the samples were found in equilibrium for calcite and $84 \%$ were found in equilibrium with dolomite i.e. groundwater is saturated with respect to calcite and dolomite. The SI for gypsum and anhydrite were found in the ranges of -1.51 to -0.71 and -1.72 to -0.39 , respectively. These findings explain why the major ions dissolve in the groundwater are $\mathrm{Ca}^{2+}, \mathrm{Mg}^{2+}, \mathrm{SO}_{4}^{2-}$ and is still the groundwater is able to dissolve anhydrite and gypsum. 


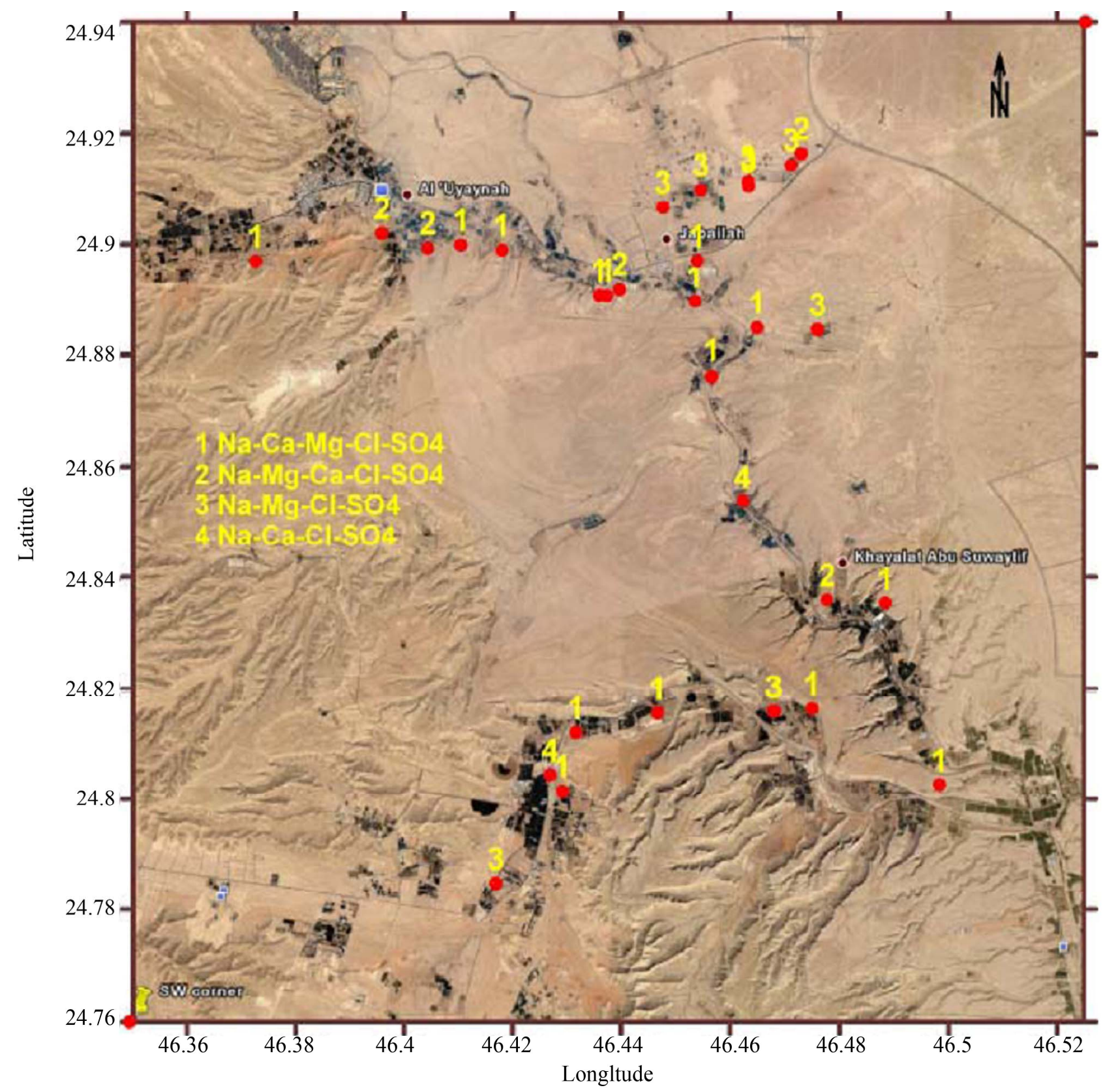

Figure 6. Spatial distribution of hydrochemical facies.

\subsection{Suitability of Groundwater}

The availability of groundwater and the suitability for various uses are inextricably intertwined. The results of the physical and chemical parameters of groundwater within the Jubaila Limestone were thus compared with the WHO standards and guidelines of 1993 [16]. It was found that the EC and the major ions exceed the standards for drinking and public health purposes. The TDS exceed the maximum limit, the $\mathrm{Na}$ in all samples exceeds $200 \mathrm{mg} / \mathrm{L}$, the $\mathrm{Cl}$ is above $250 \mathrm{mg} / \mathrm{L}$ stated by the standard. All samples except three have $\mathrm{SO}_{4}$ concentration above $500 \mathrm{mg} / \mathrm{L}$. $50 \%$ of the samples were characterized with Boron over $0.5 \mathrm{mg} / \mathrm{L}$. Thus the groundwater is not suitable for drinking purposes.

To determine suitability for livestock, the following parameters were considered: $\mathrm{EC}, \mathrm{Na}, \mathrm{SO}_{4}$, and hardness. These are the parameters most likely to limit the use of water by livestock, other factors not tested can also cause the water to be unfit. When the EC is less than 1000 $\mathrm{mS} / \mathrm{cm}$, it is unlikely that individual salts would cause health problems and no further analysis for salts is necessary. However, as the concentration of salts increases, the risk of health problems and/or reduced productivity may occur. 
Table 4. Saturation indices of calcite, dolomite and anhydrite.

\begin{tabular}{|c|c|c|c|c|}
\hline Well & Calcite & Dolomite & Gypsum & Anhydrite \\
\hline 1 & -0.1297 & -0.2346 & -0.4983 & -0.7157 \\
\hline 2 & 0.108 & 0.2488 & -0.6882 & -0.9102 \\
\hline 3 & 0.388 & 0.6904 & -0.5895 & -0.8158 \\
\hline 4 & 0.1649 & 0.2701 & -0.4092 & -0.6298 \\
\hline 5 & 0.4568 & 1.0383 & -0.9832 & -1.2262 \\
\hline 6 & 0.4842 & 0.455 & -0.5003 & -0.7214 \\
\hline 7 & 0.9916 & 2.0308 & -0.6631 & -0.8813 \\
\hline 8 & 0.4502 & 1.2715 & -1.5102 & -1.7238 \\
\hline 9 & 0.1397 & 0.2441 & -0.4458 & -0.6601 \\
\hline 10 & -0.1642 & -0.149 & -0.6332 & -0.8467 \\
\hline 11 & -0.2454 & -0.5958 & -0.5575 & -0.7722 \\
\hline 12 & 0.0794 & 0.2225 & -0.3951 & -0.6083 \\
\hline 13 & -0.1077 & -0.1027 & -0.4088 & -0.6294 \\
\hline 14 & 0.1361 & 0.5667 & -0.6482 & -0.8456 \\
\hline 15 & -0.9332 & -1.8321 & -0.2642 & -0.4774 \\
\hline 16 & 0.04 & 0.0704 & -0.2468 & -0.461 \\
\hline 17 & -0.1361 & 0.5017 & -0.9741 & -1.1711 \\
\hline 18 & 0.0746 & 0.5192 & -0.5613 & -0.7664 \\
\hline 19 & -0.2759 & -0.3595 & -0.8162 & -1.0358 \\
\hline 20 & -0.2065 & -0.0405 & -0.9284 & -1.1488 \\
\hline 21 & 0.1186 & 0.5221 & -0.8481 & -1.073 \\
\hline 22 & -0.1793 & -0.0019 & -0.8953 & -1.1158 \\
\hline 23 & -0.0549 & 0.0972 & -0.3959 & -0.6077 \\
\hline 24 & 0.2226 & 0.4716 & -0.355 & -0.5706 \\
\hline 25 & 0.4284 & 0.9204 & -0.385 & -0.5992 \\
\hline 26 & 0.349 & 0.6525 & -0.2709 & -0.5062 \\
\hline 27 & 0.0606 & 0.162 & -0.1752 & -0.3912 \\
\hline 28 & -0.2799 & -0.5958 & -0.7535 & -0.986 \\
\hline 29 & -0.2495 & -0.3619 & -0.3613 & -0.5771 \\
\hline 30 & -0.2006 & -0.316 & -0.529 & -0.7558 \\
\hline
\end{tabular}

Livestock producers in the study area have reported adult cattle surviving on water over $7500 \mathrm{mS} / \mathrm{cm}$ EC. However $\mathrm{SO}_{4}$ concentration above $500 \mathrm{mg} / \mathrm{L}$ may have laxative effects and can cause diarrhea to livestock.

Two parameters were used to test the suitability of Jubaila Limestone groundwater for irrigation purposes. These were the Magnesium Hardness (MH) and the Sodium Adsorption Ratio (SAR). The $\mathrm{MH}$ is calculated according to:

$$
\begin{aligned}
& \mathrm{MH}=\mathrm{Mg}^{2+} /\left(\mathrm{Ca}^{2+}+\mathrm{Mg}^{2+}\right) * 100 \\
& \text { The SAR was measured according to: } \\
& \mathrm{SAR}=\mathrm{Na}^{+} /\left[\left(\mathrm{Ca}^{2+}+\mathrm{Mg}^{2+}\right) / 2\right]^{1 / 2}
\end{aligned}
$$

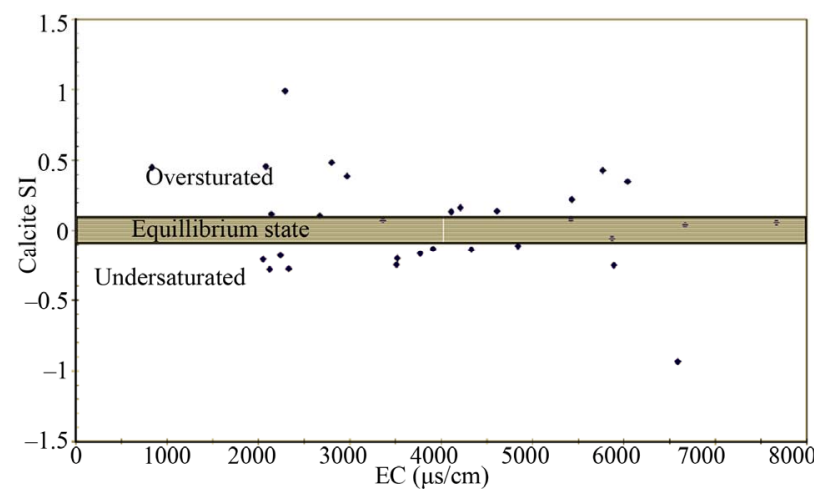

Figure 7. Saturation index of calcite in the groundwater of Jubaila limestone.

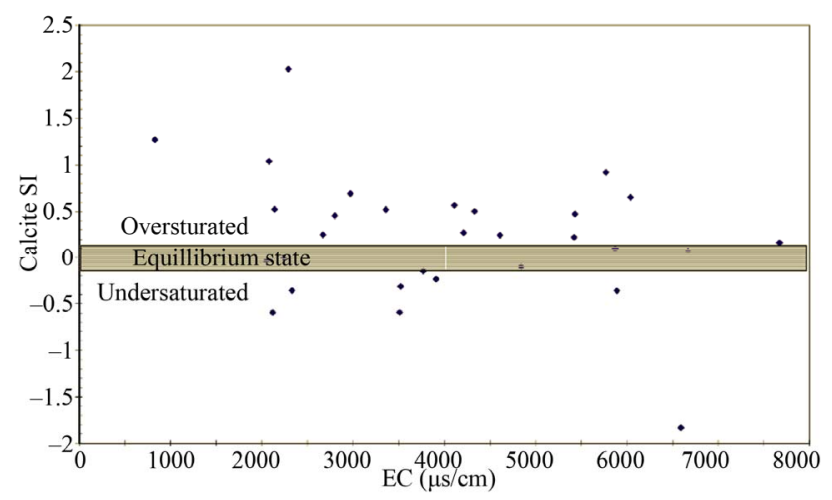

Figure 8. Saturation index of dolomite in the groundwater of Jubaila Limestone.

The concentrations of $\mathrm{Mg}^{2+}, \mathrm{Ca}^{2+}$ and $\mathrm{Na}^{+}$were in milliequivalent/liter (meq/L) in both equations.

The MH was found to range between 18.8 and 80 with an average of 49 for the collected samples, i.e. $40 \%$ of the samples exceed the maximum limit for $\mathrm{MH}$. The SAR was found to be 3.9 to 14.6 with an average of 7.9. When plotting the SAR against the Salinity Hazard on Wilcox Diagram (Figure 9), most of the samples were located in the C4-S3 and C4-S2 fields, i.e. with very high salinity hazard and high sodium hazard, and very high salinity hazard and moderate sodium hazard, respectively.

\section{Conclusion}

Groundwater occurs in the Jubaila Jurassic Limestone in fractures and within solution openings. The aquifer properties were characterized with transmissivity values of $1.7 \times 10^{-3}$ to $7.2 \times 10^{-3} \mathrm{~m}^{2} / \mathrm{s}$, and storage coefficient of $1.3 \times 10^{-4}$. The regional direction of groundwater flow in the study area is from the south towards the north with cones of depression around pumping centres. The groundwater quality varies from nearly fresh to saline waters. The main hydrochemical facies defining the groundwater composition were Na-Ca-Mg-Cl-SO ${ }_{4}, \mathrm{Na}-\mathrm{Mg}-\mathrm{Cl}-\mathrm{SO}_{4}$, 
Sodium (Alkali) hazand:

S1:Low; S2: Medium; S3: High; S4: Very high

Salinity hazand:

C1:Low; C2: Medium; C3: High; C4: Very high

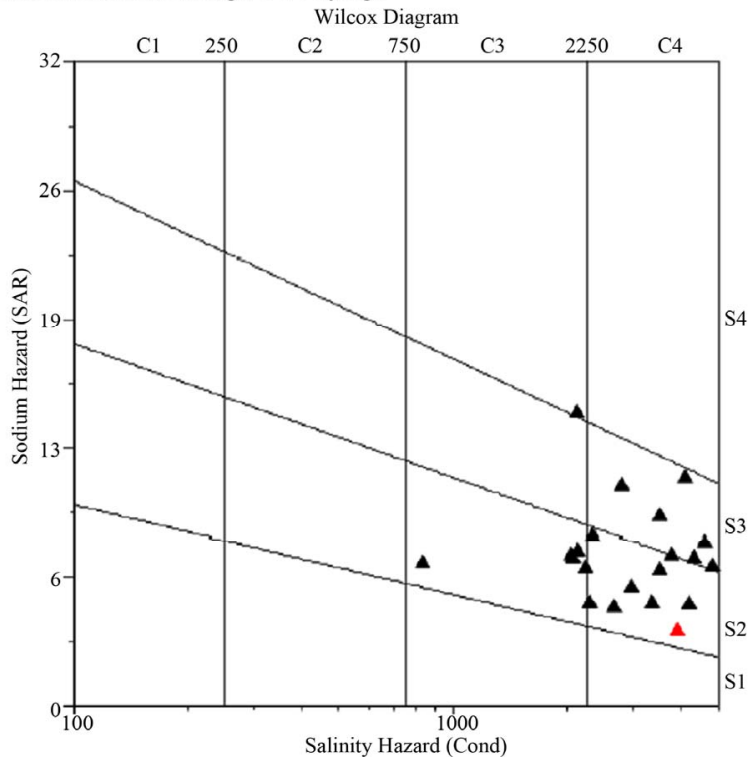

Figure 9. Wilcox diagram of SAR against salinity hazard.

and Na-Mg-Ca-Cl-SO $\mathrm{S}_{4}$. Most of the collected water samples were found to be in equilibrium with calcite and dolomite minerals but were under-saturated with respect to anhydrite and gypsum. Thus the main chemical process responsible for the quality variation was dissolution of anhydrite and gypsum. The average magnesium hardness was about 49 with $40 \%$ of the samples exceeding the maximum limit. The average SAR was found to be 7.9 and the samples were of high to very high salinity hazard, and medium to high sodium hazard. The groundwater was not found suitable for drinking purposes but can be used by livestock and for some agricultural and industrial purposes. In conclusion secondary aquifers are of great value to Saudi Arabia and more attention should be given to develop these resources in Riyadh area

\section{REFERENCES}

[1] R. Powers, L. Ramirez, C. Redmond and E. Elberg, “Geology of the Arabian Peninsula: Sedimentary Geology of Saudi Arabia," Geological Survey Professional Paper 540-D, United States Government Printing Office, Washington DC, 1966.
[2] M. Al Husseini, "Update to Late Triassic-Jurassic stratigraphy of Saudi Arabia for the Middle East Geologic Time Scale,” Geoarabia, Vol. 14, No. 2, 2009, pp. 145186.

[3] Water Atlas, "Water Atlas of Saudi Arabia," Ministry of Agriculture and Water, Saudi Arabia, 1984.

[4] A. M. Al Bassam, "Groundwater (in Arabic)," Al Humaidi Publishing House, Riyadh, 2001.

[5] D. L. Parkhurst and C. A. J. Appelo, "User's Guide to PHREEQC (Version 2)-A Computer Program for Speciation, Batch-Reaction, One-Dimensional Transport, and Inverse Geochemical Calculations,” US Geological Survey Water-Resources Investigation Report, 1999, pp. 994529.

[6] APH/AWWA/WPCF, "Standard Methods for the Examination of Water, Wastewater,” American Public Health Association, Washington DC, 1989.

[7] M. I. Al Husseini and R. Mathews, “Arabian Orbital Stratigraphy: Period Second Order Sequence Boundaries,” Geoarabia, Vol. 10, No. 2, 2005, pp. 165-184.

[8] M. I. Al Husseini and R. Mathews, "Stratigraphic Note: Orbital Calibration of the Arabian Plate Second Order Sequence Stratigraphy,” Geoarabi, Vol. 11, No. 3, 2006, pp. 161-170.

[9] G. W. Hughes, "Biofacies and Paleaoenvironments of the Jurassic Shaqra Group of Saudi Arabia,” Volumina Jurassica, Vol. VI, 2009, pp. 33-44.

[10] Parsons Basil Consultant Agriculture and Water Resources, “The Great Nafud Sedimentary Basin,” Final Report, Ministry of Agriculture and Water, Riyadh, 1969.

[11] Italconsult, "Water and Agriculture Development Studies for Area IV," Final Report, Ministry of Agriculture and Water, Riyadh, 1969.

[12] Groundwater Development Consultant (GDC), "Final Draft of Umm-Er-Radhuma Study,” Unpublished Report, Ministry of Agriculture and Water, Riyadh, 1979.

[13] R. A. Freeze and J. A. Cherry, “Groundwater," Prentice-Hall, Inc., Englewood Cliffs, 1979.

[14] A. M. Piper, "A Graphic Procedure in the Geochemical Interpretation of Water Analyses," Transactions: American Geophysical Union, Vol. 25, 1948, pp. 914-924.

[15] J. D. Hem, "Study and Interpretation of the Chemical Characteristics of Natural Water," US Geological Survey Water-Supply Paper 2254, 1985.

[16] WHO, “Guidelines for Drinking Water Quality,” World Health Organization, Geneva, 1993. 